\title{
HEAVY METAL TOLERANCE OF INDIGENOUS MICROSYMBIONTS OF ARACHIS HYPOGAEA
}

\author{
V. Nithyakalyani \\ Assistant Professor, Department of Microbiology, \\ Dr. MGR Janaki College of Arts and Science for \\ Women, Chennai, Tamil Nadu, India.
}

\begin{abstract}
In this article, the heavy metal tolerance ability of the isolated indigenous micro symbiont partner of Arachis hypogaea was gauged on the basis of specific growth rate of the strains multiplied in YEMA amended with various concentrations of heavy metals. The success of a research can be determined through the knowledge of screening strategies exerted for intense and effectual selection of influential rhizobial strain for intensified field performance by exploiting the resistance properties of Rhizobium for identification of competent strains with phytoremediation properties.
\end{abstract}

Keywords: Rhizobium; PGPR; Bioremediation; Micro symbiont

\section{INTRODUCTION}

Heavy metals discharged from industrial operations upon consequent accumulation in the environment cause drastic threat to the varied agroecosystems. Heavy metal ions at elevated levels are toxic and are excessively absorbed by roots, translocated to shoot and leads to destructive metabolism and reduced growth (Bingham et al., 1986; Foy et al., 1978). Giller et al., 1998 proposed that the impact of heavy metals is dependent on duration of exposure, dose and type of metal used. The maximal yield in symbiotic legume Rhizobium relationship, is identified to be possible only if there are favorable condition for both. Many reports indicate striking influence on microbial composition due to abnormal levels of heavy metals accumulation (Paudyal et al., 2007; Krujatz et al., 2012; Heckman et al., 1987; Broos et al., 2005) and directly or indirectly affects the health of plants including legumes like green gram, peanut and chickpea leading to impaired chlorophyll synthesis, inactivated protein synthesis, severe reduction in crop yields and loss of soil fertility (Feng et al., 2010; Bibi

\author{
J. Neenapriya \\ Assistant Professor, Department of Microbiology, \\ Dr. MGR Janaki College of Arts and Science for \\ Women, Chennai, Tamil Nadu, India.
}

\& Hussain, 2005; Semane et al., 2010; Moftah, 2000). Researchers have documented the effect of heavy metals on growth, genetic diversity, physiology and nodulation capacity of various strains of $R$. leguminosarum (Chaudhary et al., 2004; Chaudri et al., 2000; Shi et al., 2002; Ahemad \& Kibret, 2014; Hirsch et al., 1993). Pereira et al., 2006 stated that Rhizobium is a sensitive species which acts as a good indicator of soils contaminated with metals. Cevheri et al., 2011 proved the hypothesis of suppressive action of heavy metals on rhizobial cells at higher concentrations when compared to low concentrations. Despite the negative impact of heavy metals on rhizobia, phytoremediation is possible in heavy metals accumulated soil (Ma et al., 2011). Many reports support that the heavy metal resistance of rhizobial cells could be plasmid mediated or some mechanism may confer resistance (Lakzian et al., 2002; Figueira et al., 2005; Purchase \& Miles, 2001). Native rhizobial isolate conferring resistance to heavy metals is of potential importance in symbiotic association for remediation of the affected area. To execute their beneficial PGP traits under stress conditions, rhizobia possess key tolerance mechanism or pathways against abiotic stresses, heavy metals and pesticides for sustainable agriculture. Indigenous and native microbes might be more effective and competitive in combatting against the environmental stresses.

\section{EXPERIMENT ON HEAVY METAL TOLERANCE STUDIES (STANIER ET AL., 1985)}

This research deals with exploration of heavy metal tolerance ability of native rhizobial isolates obtained from Arachis hypogaea. This specific growth study to the observed stress parameter could lead to the selection of efficient isolates for agricultural practices contributing to phytoremediation.

A loop full of log phase culture of each strain was inoculated separately in flasks containing Yeast 


\section{International Journal of Engineering Applied Sciences and Technology, 2019 \\ Vol. 4, Issue 7, ISSN No. 2455-2143, Pages 136-143 \\ Published Online November 2019 in IJEAST (http://www.ijeast.com)}

Extract Mannitol broth amended with different metal concentrations of their corresponding salts $\mathrm{Al}\left(\mathrm{AlCl}_{3} \cdot 6 \mathrm{H}_{2} \mathrm{O}\right), \mathrm{Fe}\left(\mathrm{FeCl}_{3}\right), \mathrm{Co}\left(\mathrm{CoCl}_{2}\right), \mathrm{Hg}\left(\mathrm{HgCl}_{2}\right)$ and $\mathrm{Mo}\left(\mathrm{Na}_{2} \mathrm{Mo}_{4} \cdot 2 \mathrm{H}_{2} \mathrm{O}\right)$. The inoculated flasks were then placed at $28 \pm 1^{\circ} \mathrm{C}$ on shaker at speed $150 \mathrm{rpm}$. To obtain growth rate, the optical density of each flask was measured after 3 days at wavelength $610 \mathrm{~nm}$. Specific growth rate of rhizobial isolated strains were measured using the formula (Stanier et al., 1985).

Specific growth $=\log O D_{1}-\log O D_{0} \quad x 2.303$

$$
T_{1}-T_{0}
$$

Where $\mathrm{OD}_{1}=\log$ value of O.D. of culture at time $\mathrm{t}$ hour

Where $\mathrm{OD}_{0}=\mathrm{Log}$ value of O.D. of culture at time $\mathrm{t}_{0}$ hour

$\mathrm{T}_{1}-\mathrm{T}_{0}=$ Difference between time interval or duration of incubation.

\section{RESULT}

\section{Heavy Metal tolerance studies}

The overall 45 Rhizobium isolates showed a level of tolerance to heavy metals such as $\mathrm{Al}, \mathrm{Fe}, \mathrm{Co}, \mathrm{Hg} \mathrm{Mo}$ as shown in figures 1 - 15 and majority of the isolates failed to exhibit luxuriant growth above $25 \mu \mathrm{g}$ of all the heavy metals. Exceptionally, five (VRh2, VRh9, TRh11, KRh11, KRh7) isolates exhibited moderate to luxuriant growth at $150 \mu \mathrm{g}$ of all the tested heavy metals, while rest of the strains showed scanty growth at concentration $<150 \mu \mathrm{g}$ of the various metals and a reduced growth rate at concentrations $\geq 150 \mu \mathrm{g}$ of heavy metals.

\subsection{Effect of heavy metals on Tiruvallur rhizobial isolates}

Application of heavy metals was found to be inhibitory on the growth of majority of Tiruvallur isolates at concentrations above $25 \mu \mathrm{g} / \mathrm{ml}$. The specific growth rate of the isolates decreased as the concentration of metals increased from $25 \mu \mathrm{g} / \mathrm{ml}$ to $250 \mu \mathrm{g} / \mathrm{ml}$ of the applied heavy metals (Figures 1, 2, 3, 4, \& 5). However, Rhizobium TRh11 sustained its growth rate ranging from $0.35-0.4$ at higher concentrations of heavy metals. Similar observations were recorded for other metals. Majority isolates exhibited a declined growth rate in the presence of $\mathrm{Fe}$, $\mathrm{Mo}, \mathrm{Hg}$ and $\mathrm{Co}$ as the exposure to the concentrations increased. Figure 1 indicates that few of the isolates tolerated aluminium concentration but failed to tolerate $\geq 150 \mu \mathrm{g} / \mathrm{ml}$ of $\mathrm{Fe}, \mathrm{Mo}$, Co and $\mathrm{Hg}$ (Figures 2 5). Fe and Co was noted to exhibit significant growth impact on the rhizobial isolates when compared to other metals.

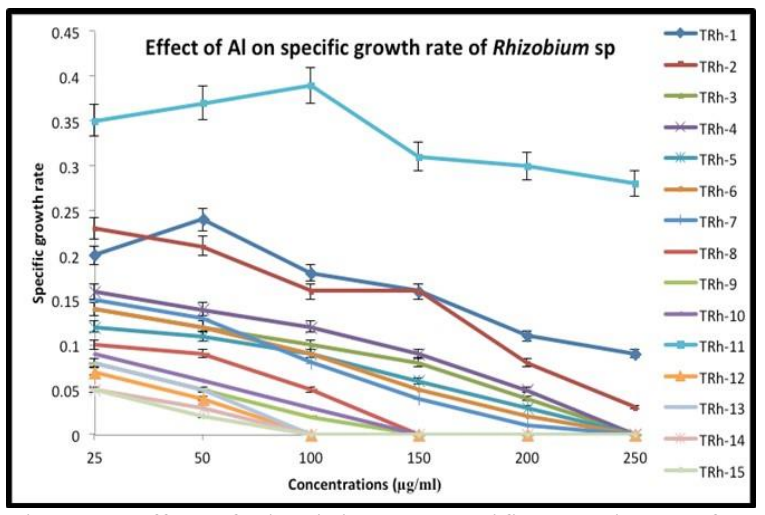

Figure 1: Effect of Aluminium on specific growth rate of Rhizobium isolates of Tiruvallur district rhizobial isolates (TRh 1-15)

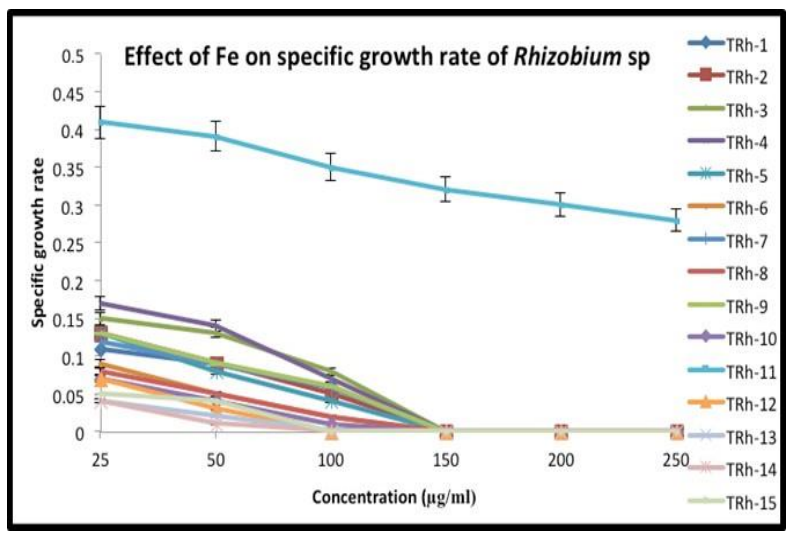

Figure 2: Effect of Ferrous on specific growth rate of Rhizobium isolates of Tiruvallur district rhizobial isolates (TRh 1-15)

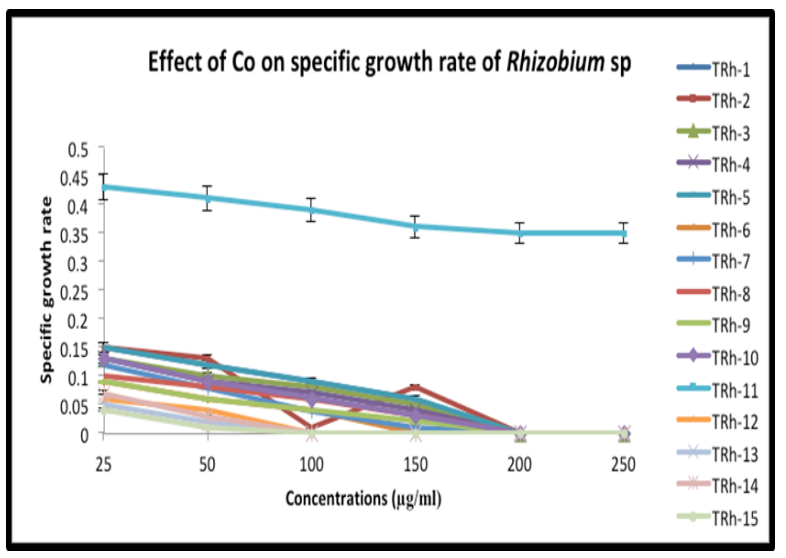

Figure 3: Effect of Cobalt on specific growth rate of Rhizobium isolates of Tiruvallur district rhizobial isolates (TRh 1-15). 
International Journal of Engineering Applied Sciences and Technology, 2019

Vol. 4, Issue 7, ISSN No. 2455-2143, Pages 136-143

Published Online November 2019 in IJEAST (http://www.ijeast.com)

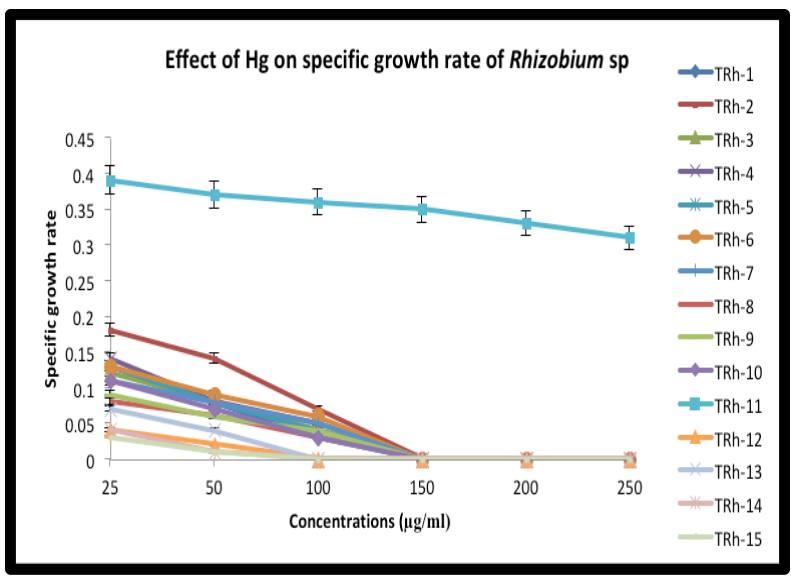

Figure 4: Effect of Mercury on specific growth rate of Rhizobium isolates of Tiruvallur district rhizobial isolates (TRh 1-15)

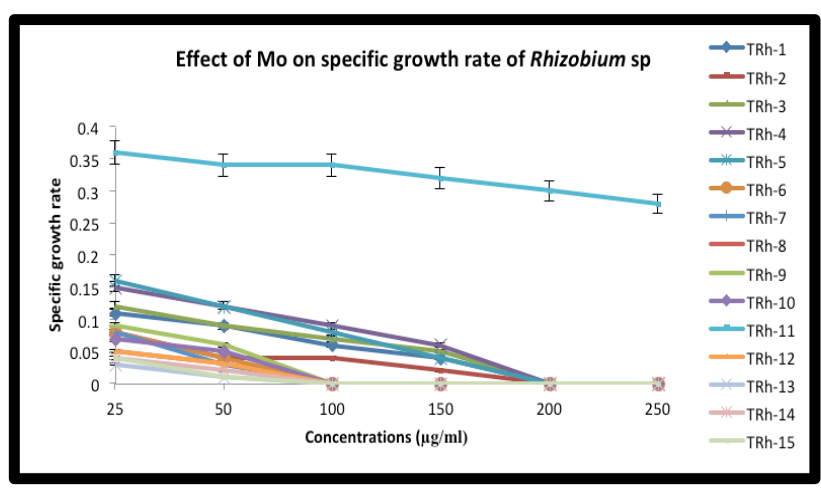

Figure 5: Effect of Molybdenum on specific growth rate of Rhizobium isolates of Tiruvallur district rhizobial isolates (TRh 1-15)

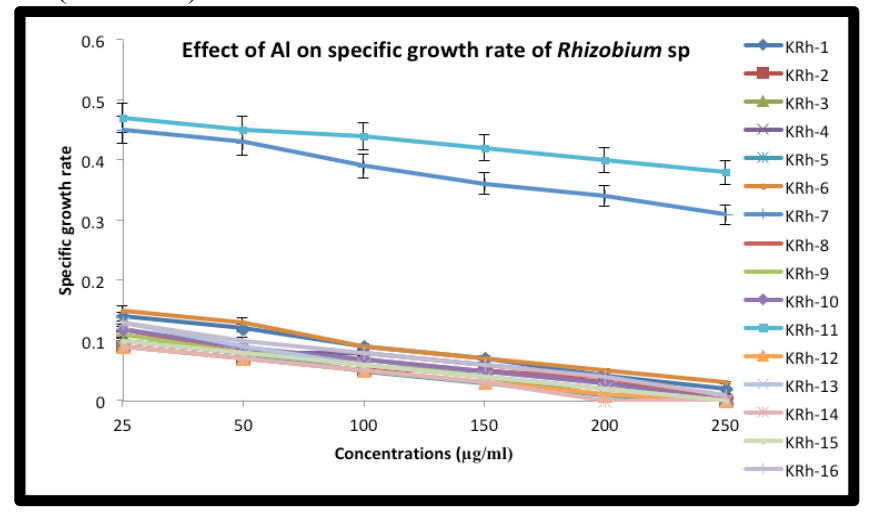

Figure 6: Effect of Aluminium on specific growth rate of Rhizobium isolates of Kanchipuram district rhizobial isolates (KRh 1-16)

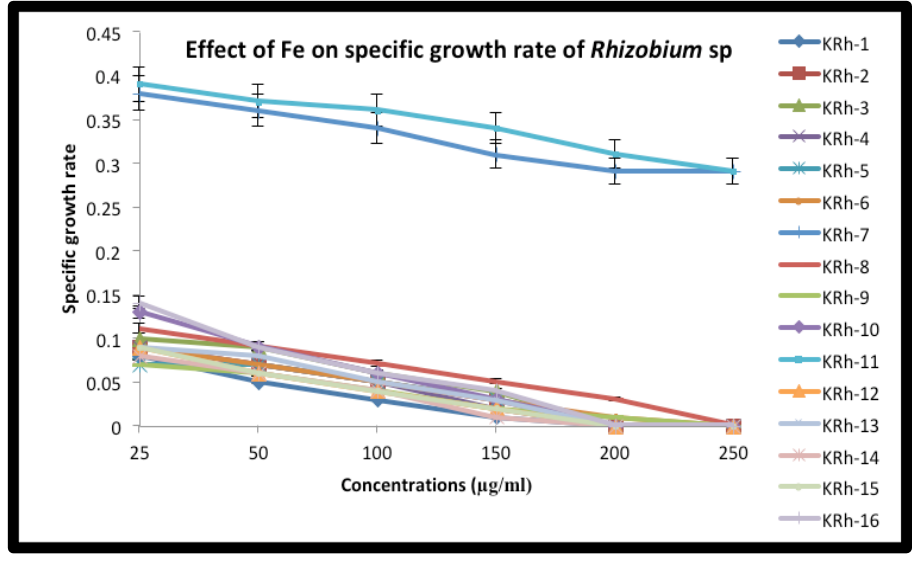

Figure 7: Effect of Ferrous on specific growth rate of Rhizobium isolates of Kanchipuram district rhizobial isolates (KRh 1-16)

\subsection{Effect of heavy metals on Kanchipuram rhizobial isolates}

Heavy metals were found beneficial up to 25 $\mu \mathrm{g} / \mathrm{ml}$ concentration to culture of isolated strains of rhizobial bacteria (Figures 6, 7, 8, 9, \& 10) isolated from Kanchipuram district of Tamil Nadu. Specific growth rate of most of the isolates in the presence of aluminium ranged from $0.1-0.2$ in $25 \mu \mathrm{g} / \mathrm{ml}-100$ $\mu \mathrm{g} / \mathrm{ml}$ respectively and declined with increasing concentrations of heavy metals. However, for KRh11 $\& \mathrm{KRh} 7$, the growth rate increased from 0.4 to 0.5 in the amended concentrations of aluminum as presented in figure 6. Similarly, in case of $\mathrm{Fe}$, the specific growth rate was $\leq 0.15$ for many isolates (Figure 7).

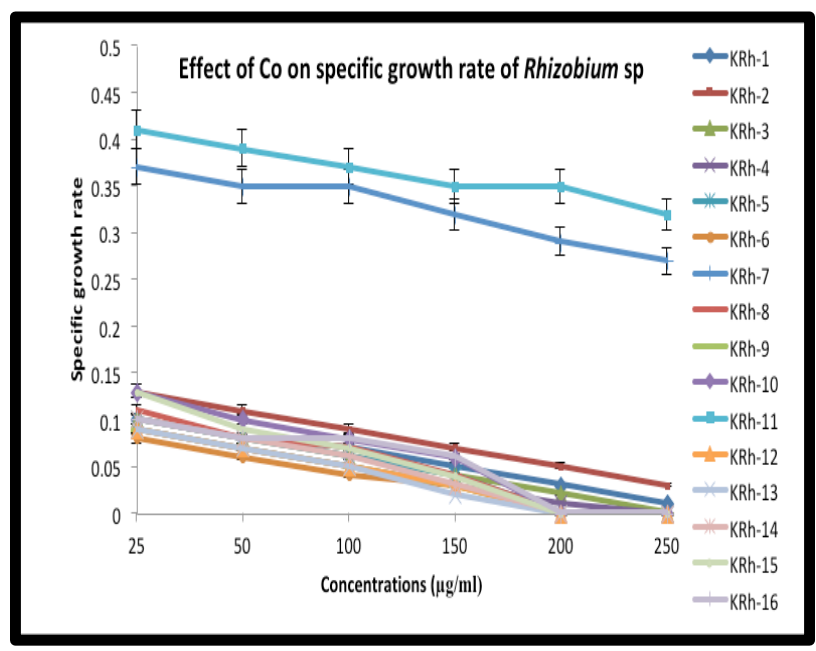

Figure 8: Effect of Cobalt on specific growth rate of Rhizobium isolates of Kanchipuram district rhizobial isolates (KRh 1-16)

High rate of specific growth was exhibited by $\mathrm{KRh} 11$ \&KRh7. A declined growth rate of few isolates were observed in the presence of Cobalt, Mercury and 
Molybdenum as the concentrations increased (Figures $8,9 \& 10)$. Of all the isolates, KRh11 \& KRh7 reached 0.45 at above $200 \mu \mathrm{g} / \mathrm{ml}$ concentrations of heavy metals.

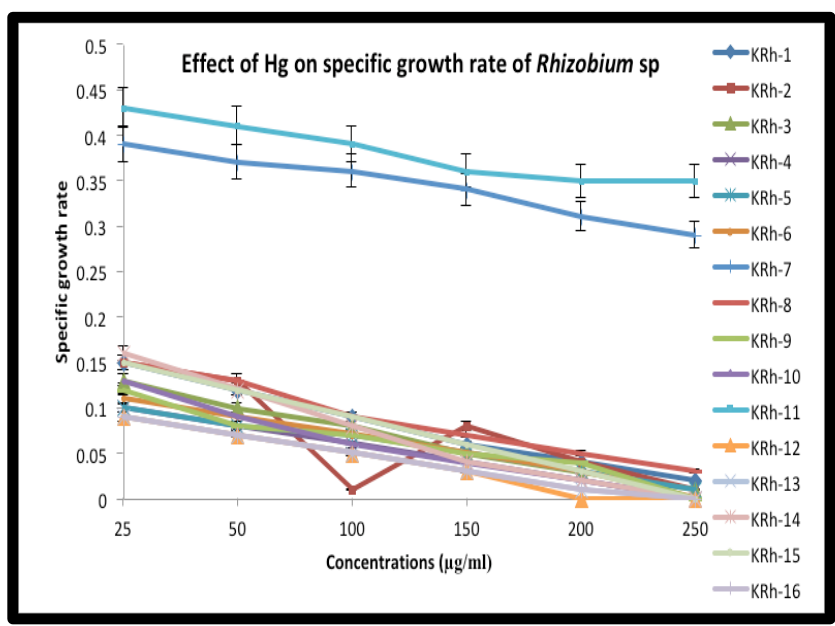

Figure 9: Effect of Mercury on specific growth rate of Rhizobium isolates of Kanchipuram district rhizobial isolates (KRh 1-16)

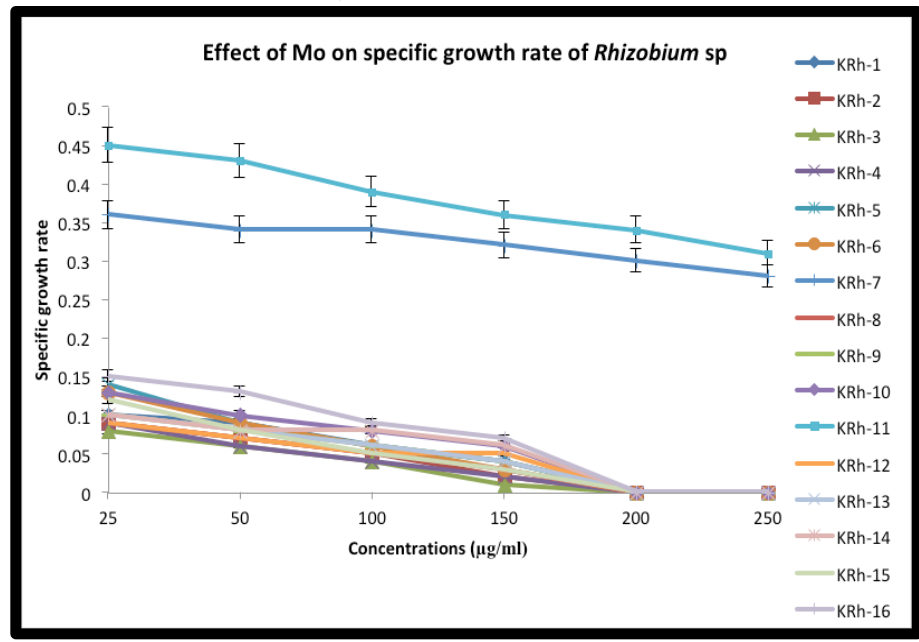

Figure 10: Effect of Molybdenum on specific growth rate of Rhizobium isolates of Kanchipuram district rhizobial isolates (KRh 1-16)

\subsection{Effect of heavy metals on Vellore rhizobial isolates}

The isolates of Vellore thrived in media amended with different heavy metals till a concentration of $150 \mu \mathrm{g} / \mathrm{ml}$. Surprisingly, two isolates VRh2 \& VRh9 reached a specific growth rate up to 0.45 at varied concentrations of the used metals in this study (Figures 11, 12, 13, $14 \& 15$ ). Beyond a certain limit, the heavy metals exhibited a negative effect on the growth rate of the isolates.

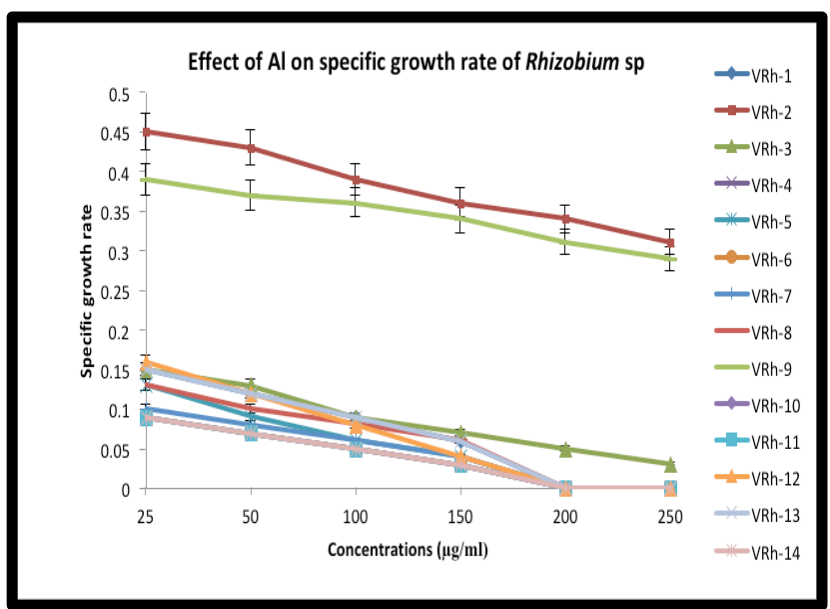

Figure 11: Effect of Aluminium on specific growth rate of Rhizobium isolates of Vellore district rhizobial isolates (VRh 1-14)

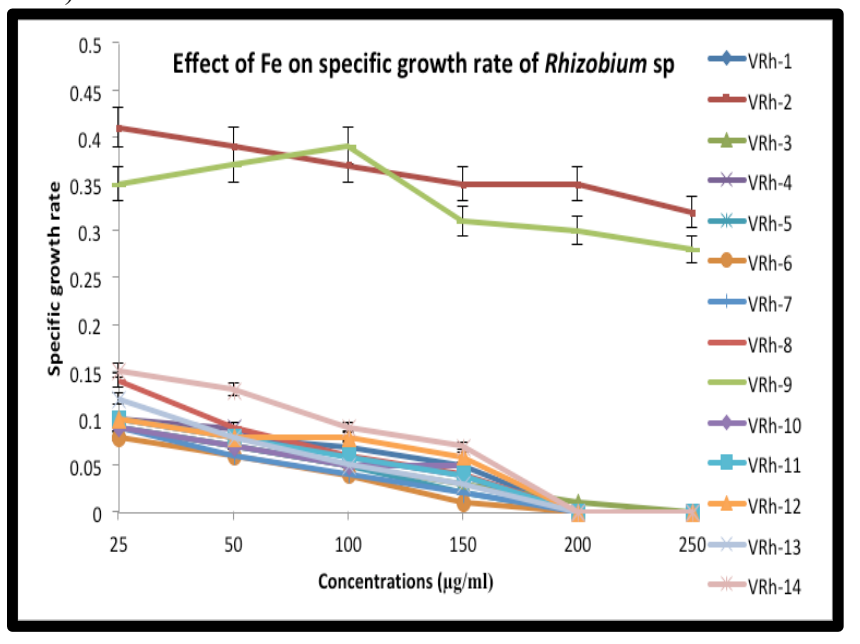

Figure 12: Effect of Ferrous on specific growth rate of Rhizobium isolates of Vellore district rhizobial isolates (VRh 1-14)

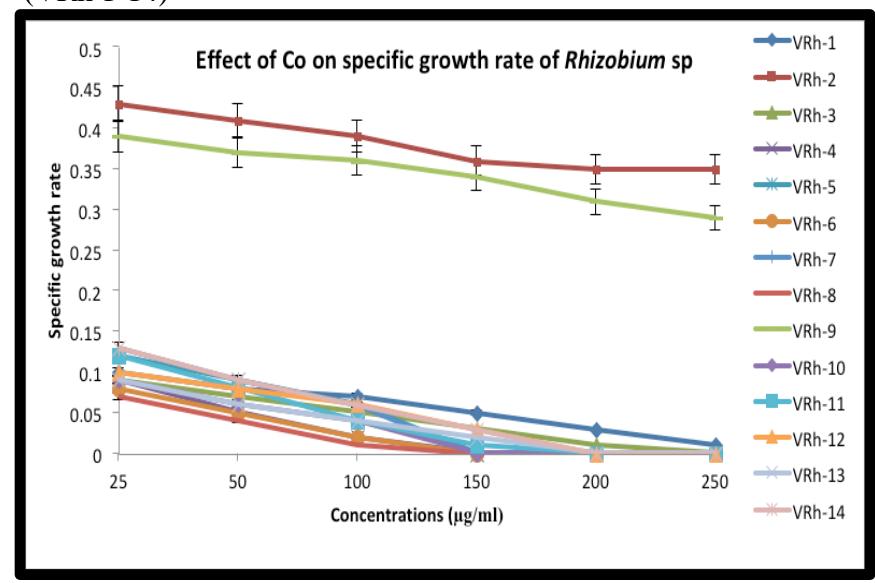

Figure 13: Effect of Cobalt on specific growth rate of Rhizobium isolates of Vellore district rhizobial isolates (VRh 1-14) 


\section{International Journal of Engineering Applied Sciences and Technology, 2019 \\ Vol. 4, Issue 7, ISSN No. 2455-2143, Pages 136-143 \\ Published Online November 2019 in IJEAST (http://www.ijeast.com)}

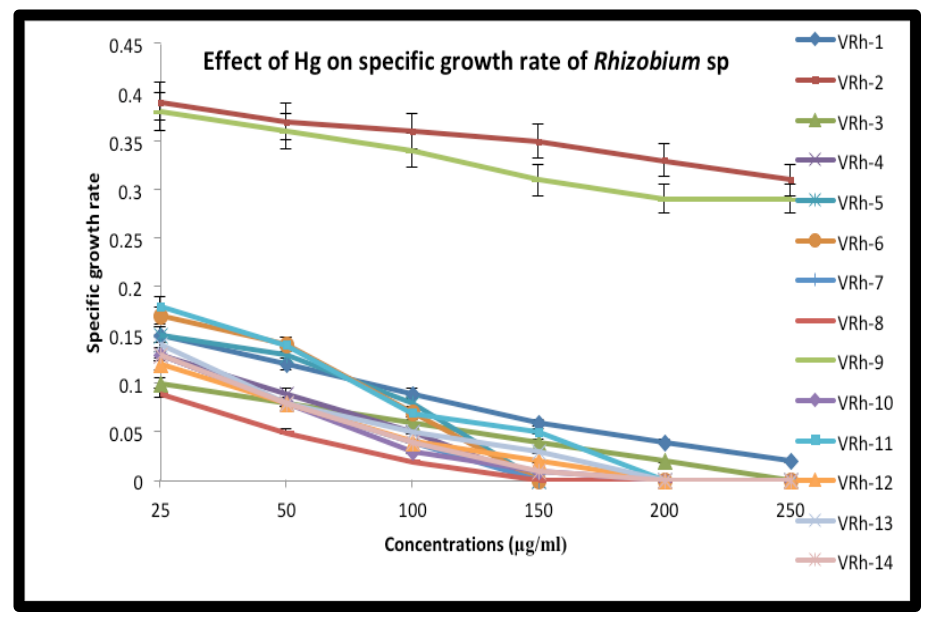

Figure 14: Effect of Mercury on specific growth rate of Rhizobium isolates of Vellore district rhizobial isolates (VRh 1-14)

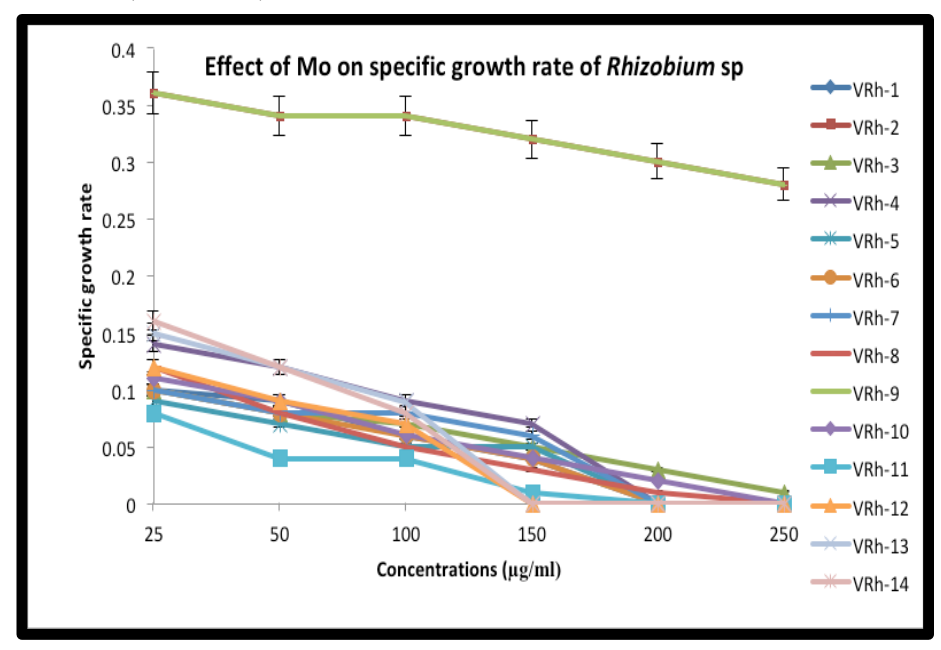

Figure 15: Effect of Molybdenum on specific growth rate of Rhizobium isolates of Vellore district isolates (VRh 1-14)

\section{DISCUSSION}

Heavy metals are inhibitory to rhizosphere microbes and processes mediated by them. Nitrogen fixation ability is lost when the partners grow in metal enriched soil (Hernandez et al., 2003). It is well known that iron is specially required for nitrogen fixing system as it is involved in the synthesis of major components like nitrogenase, leghemoglobin, ferredoxin, hydrogenase and cytochromes. Iron and molybdenum deficiency affect symbiotic partners and affects Rhizobium survival, formation of functional nodules which in turn reduces energy transfer to the bacteroides. The inhibitive effects of Mo and $\mathrm{Fe}$ on nitrate reductase activities of soil microorganisms beyond a certain limit has been observed (Solaiman, 1999). Aluminium is found to be extremely toxic than other metals. Copper is found to possess strong inhibitory effect on the rhizobial population (Arora $e t$ al., 2010). Reduction in the bacterial count at high concentrations of heavy metals and variations in the nod genes exposed to metals have been documented previously (Stan et al., 2011).

Present research investigated the effects of five different metals ( $\mathrm{Fe}, \mathrm{Al}, \mathrm{Mo}, \mathrm{Co} \& \mathrm{Hg}$ ) at different concentrations on the specific growth rate of rhizobial isolates from each location in vitro. Figures $1,2,3,4, \& 5$ indicate the specific growth rate analysis of Tiruvallur district rhizobial isolates when exposed to metals at different concentrations. At very low concentrations of heavy metals, the growth of the strains was partially inhibited. Mercury and Iron greatly affected the growth of isolates at higher concentrations as proved by the declined growth rate. Rhizobial isolate TRh11 exhibited better growth performance amongst the 15 isolates of Tiruvallur. Rane et al., 2014 recognized that few metals possessed stimulatory effect on the growth of organisms at low concentration.

Figures 6, 7, 8, 9 \&10 implies that the survival rate of Kanchipuram rhizobial isolates was predominantly low at higher concentrations of metals. The isolates showed reduced/negative growth at $\leq 150$ $\mu \mathrm{g}$ levels of metals. Numerous metals have been reported previously to inhibit the growth, morphology and activities of various groups of microorganisms (Bondarenko et al., 2010). Among the 16 isolates, $\mathrm{KRh} 11$ and $\mathrm{KRh} 7$ persisted the antagonistic effect of metals.

The Vellore isolates VRh2 and VRh9 (Figures 11, 12, 13, $14 \& 15$ ) have the ability to tolerate heavy metals such as $\mathrm{Al}, \mathrm{Fe}, \mathrm{Co}, \mathrm{Hg}$, Mo in all the studied concentrations. At higher concentrations, these metals exhibited detrimental effect on the other strains of Vellore. In a similar study, Abdel-Salam et $a l ., 2010$ determined the effect of heavy metals on the strains of rhizobia which correlate with the current findings that as the concentration of metal increased, growth of the organisms ceased. Rhizobial response to different types of metals depends on the applied concentrations (El -Hilai, 2006).

Positive relationship between the amount of heavy metals and the tolerance levels of rhizobial isolates were obvious, since five isolates were in general tolerant to all metals in the evaluated results. Many workers have demonstrated the multiple heavy metal tolerance of rhizobia (Doleman et al., 1994). Resistance mechanisms of microbes is supported by EPS and LPS of rhizobial strains which act as defense barriers against heavy metals. Principal mechanisms adopted by Rhizobium to tolerate heavy metals are accumulation of metal ions inside the cell, 


\section{International Journal of Engineering Applied Sciences and Technology, 2019 \\ Vol. 4, Issue 7, ISSN No. 2455-2143, Pages 136-143 \\ Published Online November 2019 in IJEAST (http://www.ijeast.com)}

bioreduction of the toxic metals, methylation, precipitation and chelation (Lima et al., 2006). Several findings on tolerance of rhizobial strains to heavy metals have been reported by many researchers (Milicic et al., 2006; Lakzian et al., 2002; Kuperman $\&$ Carreiro, 1997). The toxic effects of the heavy metals can be reduced through phytoremediation process and promotion of growth of the plants through PGP activities with the help of rhizobia associated with the legumes which has a great biotechnological potential (Fagorzi et al., 2018). Vidal et al., 2009 evaluated heavy metal tolerance of $M$. metallidurans. Pajuelo et al., 2011 suggested that the extrusion of heavy metals from the rhizobial cells could be attributed to resistance. Indigenous rhizobia adapting to local conditions of heavy-metal contamination are more likely to succeed over the long term compared to introducing strains which have less adaptation strategies.

\section{CONCLUSION}

These indigenous rhizobia of Arachis hypogaea plant possess ecological benefit. Therefore, productive rhizobial candidates from such environment will definitely establish successful symbioses in extreme heavy metal rich environments useful for production of crop legumes.

\section{REFERENCES}

1. Abdel-Salam, M. S., Ibrahim, S. A., Abd-El-Halim, M. M., Badawy, F. M., \& Abo-Aba, S. E. M. (2010). Phenotypic characterization of indigenous Egyptian Rhizobial strains for abiotic stresses performance. J. Am. Sci, (pp. 498503).

2. Ahemad, M., \& Kibret, M. (2014). Mechanisms and applications of plant growth promoting Rhizobacteria: current perspective. Journal of King Saud University-Science, (pp. 1-20).

3. Arora, N. K., Khare, E., Singh, S., \& Maheshwari, D. K. (2010). Effect of Al and heavy metals

on enzymes of nitrogen metabolism of fast and slow growing rhizobia under explanta conditions. World Journal of Microbiology and Biotechnology, (pp. 811-816).

4. Bibi, M., \& Hussain, M. (2005). Effect of copper and lead on photosynthesis and plant pigments in black gram [Vigna mungo (L.) Hepper]. Bulletin of environmental contamination and toxicology, (pp. 1126-1133).
5. Bingham, F. T., Pereyea, F. J., \& Jarrell, W. M. (1986). Metal toxicity to agricultural crops. Met Ions Biol Syst, (pp. 119-156).

6. Bondarenko O, Rahman PKSM, Rahman TJ, Kahru A, Ivask A (2010) Effects of rhamnolipids from Pseudomonas aeruginosa DS10-129

on luminescent bacteria: toxicity and modulation of cadmium bioavailability.

Microbiol Ecol, (pp. 588-600).

7. Broos, K., Beyens, H., \& Smolders, E. (2005). Survival of rhizobia in soil is sensitive to elevated zinc in the absence of the host plant. Soil Biology and Biochemistry, (pp. 573-579).

8. Cevheri, C., Küçük, C., \& Çetin, E. (2011). Fungicide, antibiotic, heavy metal resistance and salt tolerance of root nodule isolates from Vicia

palaestina. African Journal Biotechnology, 10 (13), 2423-2429.

9. Chaudhary, P., Dudeja, S. S., \& Kapoor, K. K. (2004). Effectivity of Host-Rhizobium leguminosarum symbiosis in soils receiving sewage water containing heavy metals. Microbiological research, 159 (2), 121127.

10. Chaudri, A. M., Allain, C. M., Barbosa-Jefferson, V. L., Nicholson, F. A., Chambers, B. J., \&

McGrath, S. P. (2000). A study of the impacts of $\mathrm{Zn}$ and $\mathrm{Cu}$ on two rhizobial species in soils of a long-term field experiment. Plant and soil, 221 (2), 167-179.

11. Doleman, P, Jansen, E, Michels, M, van Til, M (1994) Effects of heavy metals in soil on microbial diversity and activity as shown by the sensitivity-resistance index, an ecologically relevant parameter. Biol Fertil Soils 17: 177-184.

12. El - Hilai I (2006). Rhizobium-Lupine symbiosis: Micro-symbiosis biodiversity and highlighting of a multi nodular infection in Lupinus luteus.

$\mathrm{Ph}$. D Doctorate, University of Mohammed V.

Agdal., Rabat.

13. Fagorzi, C., Checcucci, A., diCenzo, G., DebiecAndrzejewska, K., Dziewit, L., Pini, F., \& Mengoni, A. (2018). Harnessing Rhizobia to

Improve Heavy-Metal Phytoremediation by Legumes. Genes, (pp. 542).

14. Feng, J., Shi, Q., Wang, X., Wei, M., Yang, F., \& $\mathrm{Xu}$, H. (2010). Silicon supplementation ameliorated the inhibition of photosynthesis and nitrate metabolism by cadmium (Cd) toxicity in Cucumis sativus L. Scientia Horticulturae, (pp. 521530).

15. Figueira, E. M. D. A. P., Gusmão Lima, A. I., \& Pereira, S. I. A. (2005). Cadmium tolerance plasticity in Rhizobium leguminosarum bv. 


\section{International Journal of Engineering Applied Sciences and Technology, 2019 Vol. 4, Issue 7, ISSN No. 2455-2143, Pages 136-143 \\ Published Online November 2019 in IJEAST (http://www.ijeast.com)}

viciae: glutathione as a detoxifying agent. Canadian journal of microbiology, (pp. 7-14).

16. Foy, C. D., Chaney, R. T., \& White, M. C. (1978). The physiology of metal toxicity in plants. Annual review of plant physiology, (pp. 511-566).

17. Giller, K. E., Witter, E., \& Mcgrath, S. P. (1998). Toxicity of heavy metals to microorganisms and microbial processes in agricultural soils: a review. Soil biology and biochemistry, (pp. 1389-1414).

18. Heckman, J. R., Angle, J. S., \& Chaney, R. L. (1987). Residual Effects of Sewage Sludge on Soybean: II. Accumulation of Soil and Symbiotically Fixed Nitrogen 1. Journal of Environmental Quality, (pp. 118-124).

19. Hernandez, L., Probst, A., Probst, J. L., \& Ulrich, E. (2003). Heavy metal distribution in some French forest soils: evidence for atmospheric contamination. Science of the Total Environment, (pp. 195-219).

20. Hirsch, P. R., Jones, M. J., McGrath, S. P., \& Giller, K. E. (1993). Heavy metals from past applications of sewage sludge decrease the genetic diversity of Rhizobium leguminosarum biovar trifolii populations. Soil Biology and Biochemistry, (pp. 1485-1490).

21. Krujatz, F., Haarstrick, A., Nörtemann, B., \& Greis, T. (2012). Assessing the toxic effects of nickel, cadmium and EDTA on growth of the

plant growth-promoting rhizobacterium Pseudomonas brassicacearum. Water, Air, \& Soil Pollution, (pp.1281-1293).

22. Kuperman RG, Carreiro MM (1997). Soils heavy metal concentration, microbial biomass and enzyme activities in a contaminated grassland ecosystem. Soil Biol Biochem, (pp. 179190).

23. Lakzian, A., Murphy, P., Turner, A., Beynon, J. L., \& Giller, K. E. (2002). Rhizobium leguminosarum bv. viciae populations in soils with increasing heavy metal contamination: abundance, plasmid profiles, diversity and metal tolerance. Soil Biology and Biochemistry, (pp. 519-529).

24. Lima, A. I. G., Corticeiro, S. C., \& Figueira, E. M. D. A. P. (2006). Glutathione-mediated cadmium sequestration in Rhizobium leguminosarum. Enzyme and microbial technology, (pp.763-769).

25. Ma, Y., Prasad, M. N. V., Rajkumar, M., \& Freitas, H. (2011). Plant growth promoting rhizobacteria and endophytes accelerate phytoremediation of metalliferous soils. Biotechnology advances, (pp. 248258).
26. Madhavi D Rane, Eshrat A Shaikh, Ulka G Malusare. (2014). Effect of Heavy Metals on Growth of Rhizobium. International Journal of Scientific \& Engineering Research, (pp. 306-310).

27. Miličić B, Delić D, Stajković O, Rasulić N, Kuzmanović Đ, Jošić D (2006) Effects of heavy metals on rhizobial growth. Rom Biotech

Lett, (pp. 2995-3003).

28. Mohamad, R., Maynaud, G., Le Quéré, A., Vidal, C., Klonowska, A., Yashiro, E., \& Brunel, B. (2017). Ancient heavy metal contamination in soils as a driver of tolerant Anthyllis vulneraria rhizobial communities. Appl. Environ. Microbiol., (pp. 1735-16).

29. Pajuelo, E., Rodríguez-Llorente, I. D., Lafuente, A., \& Caviedes, M. Á. (2011). LegumeRhizobium symbioses as a tool for bioremediation of heavy metal polluted soils. In Biomanagement of metal-contaminated soils (pp. 95-123). Springer Netherlands.

30. Paudyal, S. P., Aryal, R. R., Chauhan, S. V. S., \& Maheshwari, D. K. (2007). Effect of heavy metals on growth of Rhizobium strains and symbiotic efficiency of two species of tropical

legumes. Scientific World, (pp. 27-32).

31. Pereira, S. I. A., Lima, A. I. G., \& Figueira, E. M. D. A. P. (2006). Heavy metal toxicity in Rhizobium leguminosarum biovar viciae isolated from soils subjected to different sources of heavy-metal contamination: effects on protein expression. Applied Soil Ecology, (pp. 286293).

32. Pereira, S. I. A., Lima, A. I. G., \& Figueira, E. M. D. A. P. (2006). Screening possible mechanisms mediating cadmium resistance in Rhizobium leguminosarum bv. viciae isolated from contaminated Portuguese soils. Microbial ecology, (pp. 176-186).

33. Purchase, D., Miles, R. J., \& Young, T. W. (1997). Cadmium uptake and nitrogen fixing ability in heavy-metal-resistant laboratory and field strains of Rhizobium leguminosarum biovar trifolii. FEMS Microbiology Ecology, (pp. 85-93).

34. Semane, B., Dupae, J., Cuypers, A., Noben, J. P., Tuomainen, M., Tervahauta, A., \& Vangronsveld, J. (2010). Leaf proteome responses of Arabidopsis thaliana exposed to mild cadmium stress. Journal of Plant Physiology, (pp.247-254).

35. Shi, W., Bischoff, M., Turco, R., \& Konopka, A. (2002). Long-term effects of chromium and lead upon the activity of soil microbial communities. Applied Soil Ecology, (pp. 169-177). 
International Journal of Engineering Applied Sciences and Technology, 2019

Vol. 4, Issue 7, ISSN No. 2455-2143, Pages 136-143

Published Online November 2019 in IJEAST (http://www.ijeast.com)

36. Solaiman, A.R.M. (1999). Effects of Bradyrhizobium japonicum inoculation and molybdenum on soybean. Bangaladesh J. Bot., (pp. 181-183).

37. Stan V, Gament E, Corena CP, Voaides C, Dusa M, Plopeanu G (2011). Effects of heavy metal from polluted soils on

the Rhizobium diversity. Not Bot Hort Agrobot Cluj., (pp.88 -95).

38. Stanier, R.Y., Adelberg, E.A. and Ingraham, J.L. (1985). Microbial growth. In General Microbiology MacMillan Publication London. (Pp 273-293).

39. Vidal, C., Chantreuil, C., Berge, O., Maure, L., Escarre, J., Bena, G., \& Cleyet-Marel, J. C. (2009).

Mesorhizobium metallidurans sp. nov., a metalresistant symbiont of Anthyllis vulneraria growing on metallicolous soil in Languedoc, France. International Journal of Systematic and Evolutionary Microbiology, (pp. 850-855).

\section{ACKNOWLEDGEMENT:}

Nithyakalyani acknowledges her guide Dr. Kannan and Ms. J. Neenapriya for their support and guidance. 